\title{
The method of selecting an integrated development territory for the high-rise unique constructions
}

\author{
Svetlana Sheina ${ }^{1 *}$,Elina Shevtsova ${ }^{1}$, Alexander Sukhinin ${ }^{1}$ and Elena Priss ${ }^{2}$ \\ ${ }^{1}$ Academy of Construction and Architecture of Don State Technical University, Rostov-on-Don, \\ Russia. \\ ${ }^{2}$ Don State Technical University, sq. Gagarina, 1, Rostov-on-Don, 344010, Russia
}

\begin{abstract}
On the basis of data provided by the Department of architecture and urban planning of the city of Rostov-on-don, the problem of the choice of the territory for complex development that will be in priority for the construction of high-rise and unique buildings is solved. The objective of the study was the development of a methodology for selection of the area and the implementation of the proposed method on the example of evaluation of four-territories complex development. The developed method along with standard indicators of complex evaluation considers additional indicators that assess the territory from the position of high-rise unique building. The final result of the study is the rankings of the functional priority areas that takes into account the construction of both residential and public and business objects of unique high-rise construction. The use of the developed methodology will allow investors and customers to assess the investment attractiveness of the future unique construction project on the proposed site.
\end{abstract}

\section{Introduction}

In the XXI century on the territory of large cities a top priority of urban activity is the reconstruction of urban development. It happens so because every year the need for new construction of residential, public and commercial buildings increases to meet the needs of the population, but suitable areas for new construction in the city are almost gone. The maximum density of urban development is achieved in the Central part of the city, and the remaining areas that suitable for new construction are too small. In this regard, increases the popularity of high-rise unique building being an effective solution for construction in the dense urban areas and a small area of land.

The Government of the Russian Federation faced the problem of search of new territories, meeting the demands of investors, developers and the population in general. The program of complex development of territories was developed by the Government of the Russian Federation, which is based on the optimum economic development of territories due to the demolition of dilapidated housing and low-value buildings, removal of industrial enterprises outside the city and reconstruction of existing buildings. Integrated development of territories

* Corresponding author: rgsu-gsh@mail.ru 
is possible on the initiative of the right holders of land plots and (or) located on them objects of real estate [1], or on the initiative of local authorities [2]. Under this program the Department of Architecture and Urban planning of the city of Rostov-on-Don marked four areas within which a decision may be taken on the complex development on the initiative of local authorities.

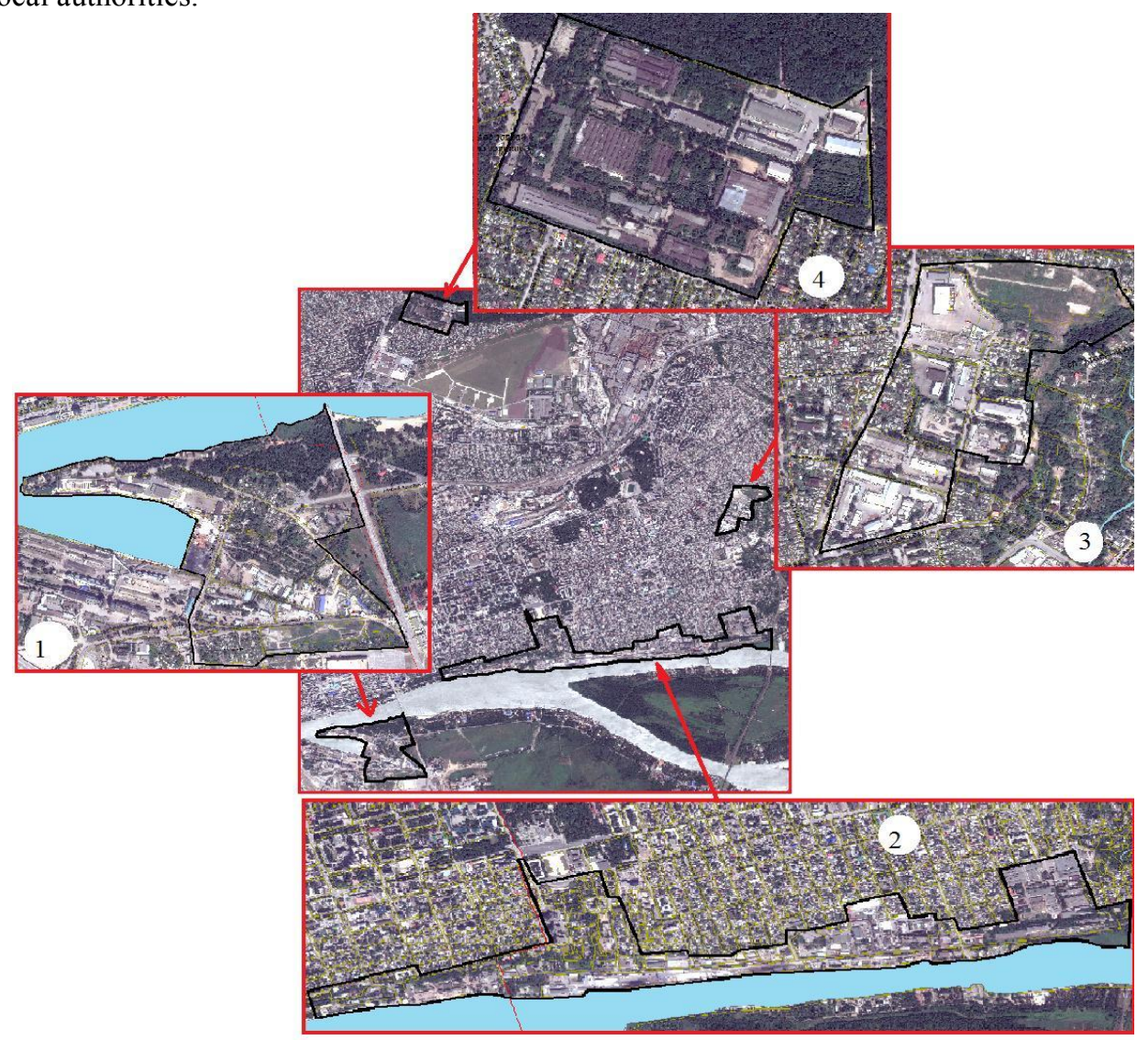

Fig. 1.A fragment of the electronic map of the city of Rostov-on-Don $(1,2,3,4$ - areas of integrated development)

The study of the areas for complex development helped to identify the problem of assessing their suitability for high-rise unique building. The objective of the study was the development of a methodology of selection of priority areas and the implementation of the proposed method on the example of evaluation of four territories complex development. The choice of the most priority areas is based on the techniques of a complex assessment of the territory, taking into account additional factors, evaluating the territory from a position of allocation of a unique high-rise buildings.

\section{Materials and methods}

To solve this problem, we developed a methodology of choice of the territories for integrated development of unique high-rise buildings. The developed methodology includes the following metrics (figure 2): 


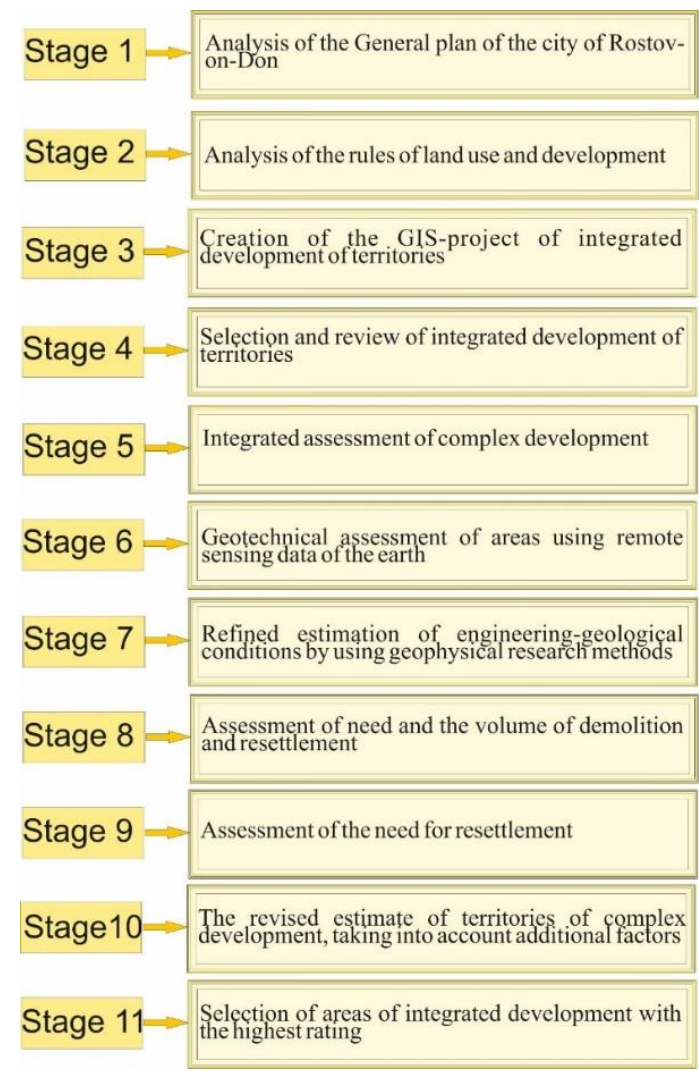

Fig. 2. The method of selection of areas of integrated development for high-rise and unique buildings

Stage 1: Analysis of the General plan of the city of Rostov-on-Don

Analysis the General plan of the city is based on the electronic map of the city of Rostov-onDon in PC ArcGis 10.1

Stage 2: Analysis of the rules of land use and development

Analysis of the rules of land use and development is based on the electronic map of the city of Rostov-on-Don in PC ArcGis 10.1

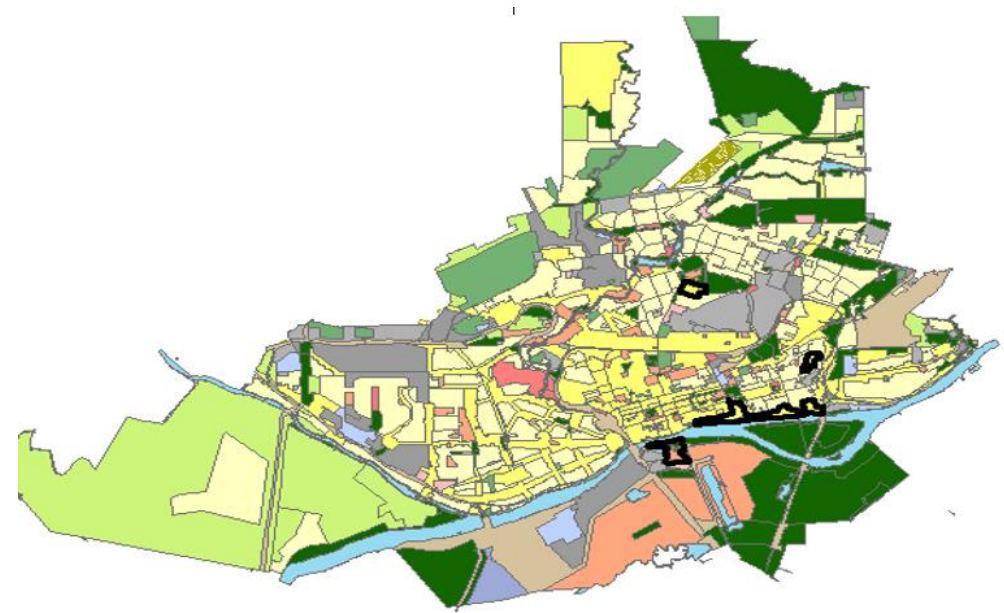

Fig. 3. Map of the city of Rostov-on-Don 
Stage 3: Creation of the GIS-project of integrated development of territories In ArcMap 10.1 GIS database of the territories complex development of the city of Rostovon-Don is designed and developed. In the electronic map of Rostov-on-Don the above described territory was applied, which is divided into four modules.

The first module contains the general characteristics of the areas (location areas, perimeter, area, compliance with the rules of land use and development). The second module contains information about engineering-geological conditions of territories (rate of rise of the groundwater, the depth of the groundwater, the presence of landslides, type of soil, flooding floods and geological hazards). The third module is the data on the ecological risk of territory and density of noise pollution. The fourth module of the GIS database contains information about the investment attractiveness of the territory (zones of protection of monuments of history, the degree of accessibility to the city center, security engineering equipment and the data of rating of functional territory priority depending on the type of the placed object)

Stage 4: Selection and review of integrated development of territories

Using the GIS-project of integrated development of territories, at this stage the general idea of the territories of complex development, their location on the city map, the land area, the positive and negative aspects of each territory.

Stage 5: Integrated assessment of complex development

Complex assessment of the territory is formed on the result of comparing the components' estimates from the point of view of the usage in various purposes: industrial construction, agriculture and forestry, for the formation of residential zones and zones of mass rest of the population. The goal of a complex site assessment is determining the degree of its suitability for different uses.

The territory of Rostov-on-Don was divided into pieces of land for evaluation, occupied by various land use categories. For the boundaries of the assessment sites were taken natural boundaries, boundaries of land occupied by large engineering structures, boundaries of enterprises, agricultural and forestry land.

In this study as the indicators of a complex assessment of the territory there were taken the factors of the relative values used in the assessment of land settlements [3]:

- Availability of public business, the administrative center;

- The level of engineering arrangement (communications, transport);

- The level of development of the sphere of cultural-and-everyday service of the population;

- Existence of monuments of history and culture;

- State of the environment;

- Engineering-geological conditions affecting the construction;

- Landscape and recreational terms.

Based on these factors, the calculation of the coefficients of relative values of the area are made. The numerical values of the coefficients for each of the assessment sites for each of the 7 groups of factors are summarized using the following formula:

$$
\mathrm{K}=1+\mathrm{K}_{1}+\mathrm{K}_{2}+\mathrm{K}_{3}+\mathrm{K}_{4}+\mathrm{K}_{5}+\mathrm{K}_{6}+\mathrm{K}_{7} ;
$$

$\mathrm{K}$-is the total value of the coefficient of relative values of the assessment area; $\mathrm{K} 1-\mathrm{K} 7$-is a sum of the values of the coefficients of the factors (from 1 to $7 \mathrm{gr}$.).

The methods of selecting of the priority areas for the complex development imply a solution of the problem of choosing the evaluation criteria of these territories from the point of view of their attractiveness for certain types of their priority functional use. For solution of this task the determination of the coefficients of the desirability of evaluation factors of each function is fulfilled. Further the calculation of the integral index of investment attractiveness of the given area for a given function takes place [3]. 
To assess the degree of influence of the $\mathrm{i}$ - evaluation factor on the investment attractiveness of the area for the specified function the coefficient of desirability is entered, whose values are established on the basis of expert recommendations (table 1).

Table 1. Scale of values of the coefficients of the desirability

\begin{tabular}{|c|l|c|}
\hline Rang & \multicolumn{1}{|c|}{ Evaluation } & $K_{g}$ \\
\hline 1 & Critically necessary & 4 \\
\hline 2 & highly desirable & 2 \\
\hline 3 & preferably & 1 \\
\hline 4 & doesn't matter & 0 \\
\hline 5 & undesirable & -1 \\
\hline 6 & highly undesirable & -2 \\
\hline 7 & critically undesirable & -4 \\
\hline
\end{tabular}

Calculation of ratings is performed according to the formula:

$$
A_{i}=K_{\mathrm{g} i} * K_{i}
$$

$\mathrm{A}_{\mathrm{i}}$-is the rating-dependent valuation factors

$\mathrm{K}_{\mathrm{gi}}$ - the coefficient of the desirability of the $\mathrm{i}$ - evaluation factor

$\mathrm{K}_{\mathrm{i}}$ - is the coefficient of relative values of the i- station.

The final integrated ranking of the estimates are obtained by the formula:

$$
A_{j}=\sum_{i=1}^{n} A_{i}+C
$$

$A_{j^{-}}$-integrated rating score, $\mathrm{C}=10$.

Thus, based on the study of the methodology of integrated assessment the rating of the functional priority of the territories complex development with the help of IAS "a simulation model of the master plan" that is available on the Department of urban construction and economy of ACA DSTU, which automatically calculates the rating depending on the specific evaluation of the site and of its functional use.

The final rating assessment of the territory was calculated by the formula:

$$
B=\left(A_{1}+A_{2}+\cdots+A_{n}\right) / n
$$

$\mathrm{B}$ is the final rating assessment of the territory,

$A_{n}$-the rating of the n- section,

$\mathrm{n}$ is the number of plots on site.

The results of the calculations are presented in table 2 .

Table 2. Rating of the functional priority of the territories of complex development

\begin{tabular}{|l|c|c|}
\hline \multirow{2}{*}{$\mathrm{N}$} & \multicolumn{2}{|c|}{ The rating depending on the function } \\
\cline { 2 - 3 } & Residential area & Public-business zone \\
\hline Area No 1 & 12.84 & 11.63 \\
\hline Area No 2 & 14.7 & 12.95 \\
\hline Area No 3 & 11.25 & 11.06 \\
\hline Area No 4 & 12.12 & 11.73 \\
\hline
\end{tabular}

According to the functional priority of the highest priority for the construction of residential, public and business buildings is the area No2. 
Step 6: Geotechnical assessment of areas using remote sensing data of the earth

Earth remote sensing (ERS) - obtaining information about the Earth's surface and objects on it by contactless methods, in which a registered device is deleted from object of research to a considerable distance. The method consists of interpreting the results of measurement of electromagnetic radiation reflected or emitted by the object and is registered in some remote from it space.

Remote sensing techniques are based on the use of sensors that are placed on the spacecraft and record the electromagnetic radiation adapted for digital processing formats.

Radar interferometry - processing method of radar data based on the allocation of the phase difference of signals reflected from different parts of the area. It allows to calculate the path traversed by radio waves to the Earth's surface and, consequently, to obtain highprecision information about the absolute elevation of the terrain and the displacement of the surface caused by different factors.

The use of interferometric radar gives the ability to monitor:

- landslides;

- dynamics of process of wetting of the soil massifs;

- subsidence and suffosion deformations;

vertical displacements of buildings, structures, pavements, etc.

To monitor the city of Rostov-on-Don was used remote sensing data of the radar satellites COSMO-SkyMed-1-4 for the period from may 2011 to November 2013. The image processing performed by the software ENVI and SARscape Intererometric Stacking. As a result of processing of images of the array 3000-30000 points on $\mathrm{m}^{2}$ and evaluated the dynamics of the displacements of points in millimeters.

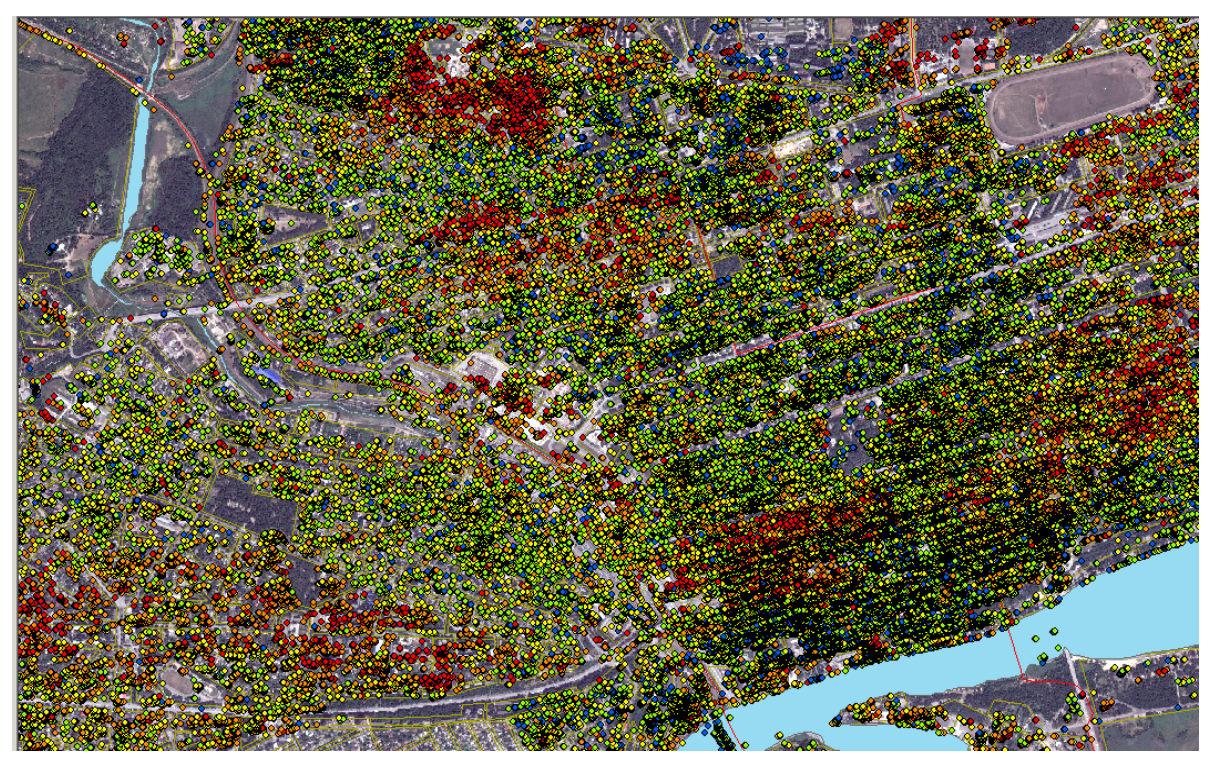

Fig. 4. Pockets of vertical offsets of the city of Rostov-on-Don, obtained on the basis of data of interferometric photography. Red dots indicate significant subsidence of the earth's surface

On the basis of remote sensing it is possible to draw the conclusions about the possibility of further building development and feasibility of construction in the area based on the information of the vertical displacements of the earth surface. Comparative analysis of the territories complex development of the city of Rostov-on-Don on the basis of interferometric photography is presented in table 3 . 
Table 3. Analysis of data of remote sensing for integrated development of territories

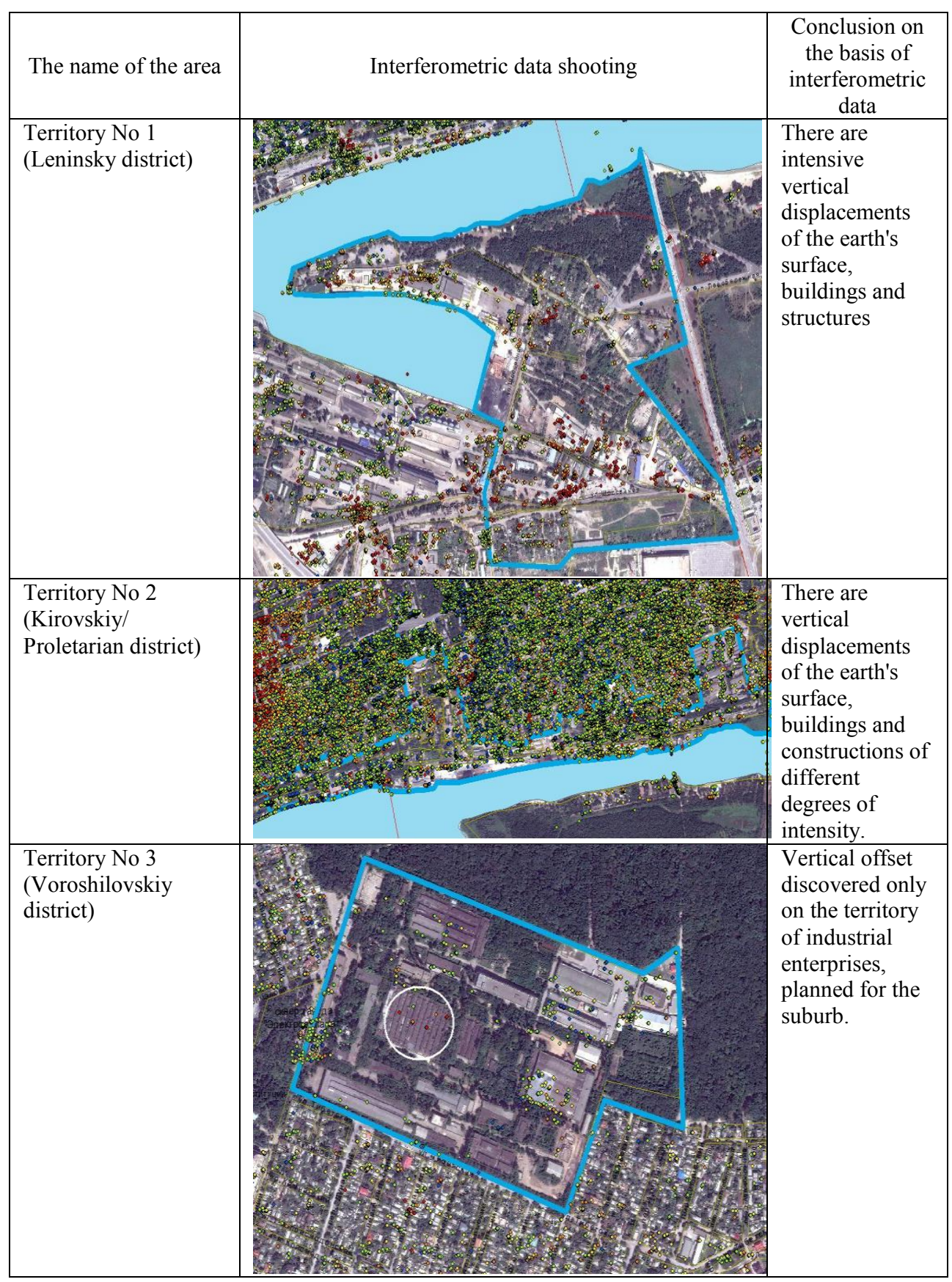




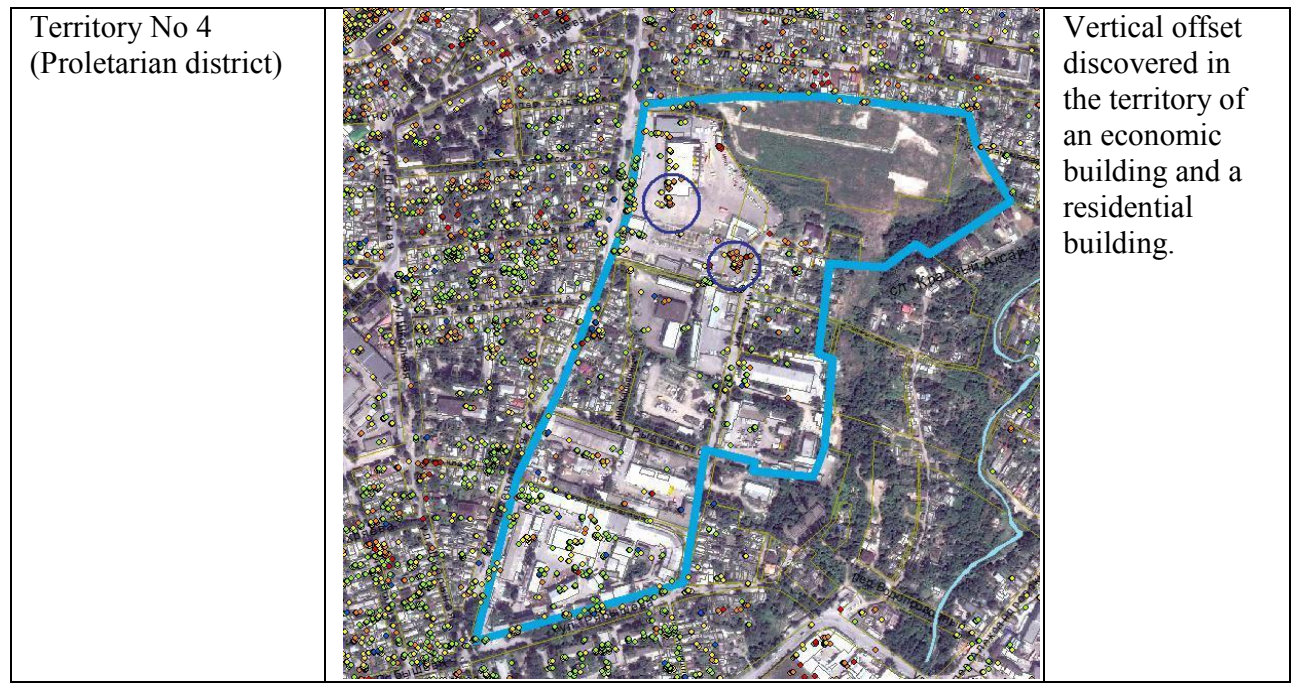

Step 7: Refined estimation of engineering-geological conditions by using geophysical research methods

For an updated assessment of engineering-geological conditions of territories of complex development, one should choose methods that are not accompanied by high noise or vibration impacts. These methods include ground-penetrating radar and seismic low-power oscillators. The use of these methods does not require space for the deployment of equipment, and can be used in dense urban areas. These methods provide the opportunity to assess the volume status of the soil, its properties and structure, to determine the representativity of the drilling and to compare the results of sampling soil and spot methods.

GPR method is based on the emission of pulses of electromagnetic waves and detecting signals reflected from different objects in the sensed environment. The result of the GPR studies is the radargram. The horizontal axis of radargram - axis profile (in meters), the vertical axis of radargram - time axis beginning at the time of sending the probe pulse (figure 5).

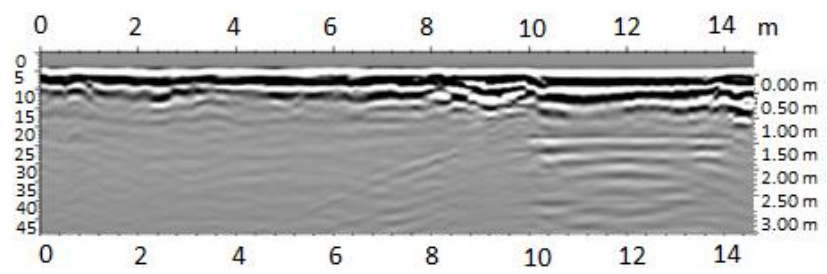

Fig. 5. Radargram

The principle of operation of the seismic low-power oscillators is based on the discharge of cargo from a height of $6-8$ meters. The moment of contact of the load surface of the soil is marked by a special device, and is transmitted as marking the beginning of the excitation on the seismic station. Seismic exploration allows to evaluate the physical properties of the soil, which can then confirm the verification by drilling.

In the territories of the integrated development was used both geophysical method of investigation, which resulted in the specification of the engineering geological conditions of territories complex development and definition of the boundary of occurrence of loess forest subsidence of soils of different types. After receipt of finalized results were built GIS 
electronic map in ArcGIS 10.1, which will be applied as the basis for selecting the priority areas of complex development.

Stage 8-9: Assessment of need and the volume of demolition and resettlement

For assessing the need for relocation and demolition in the territories of complex development it is necessary to estimate the number of existing buildings and their functionality. For the evaluation based on electronic maps and satellite images of Rostov-onDon, which revealed the following:

Table 4. Number of buildings of various functional purposes in the territories of the integrated development

\begin{tabular}{|l|c|c|c|c|}
\hline & Territory No1 & Territory No2 & Territory No3 & Territory No4 \\
\hline $\begin{array}{l}\text { Residential } \\
\text { building }\end{array}$ & 0 & $\begin{array}{c}>100 \\
\text { buildings }\end{array}$ & 0 & 0 \\
\hline $\begin{array}{l}\text { Industrial } \\
\text { buildings }\end{array}$ & $\begin{array}{c}30-40 \\
\text { buildings }\end{array}$ & $\begin{array}{c}20-30 \\
\text { buildings }\end{array}$ & 32 buildings & 23 buildings \\
\hline $\begin{array}{l}\text { Administrative } \\
\text { building }\end{array}$ & 15 buildings & 0 & 2 buildings & 18 buildings \\
\hline
\end{tabular}

Thus, the greatest levels of relocation and demolition are required on territory No. 2 due to the large number of residential buildings (100 buildings).

Stage 10: The revised estimate of territories of complex development, taking into account additional factors

As additional factors to the revised site assessment, taking into account the unique construction of high-rise buildings, the following additional indicators were pointed out:

- Analysis of the need for resettlement and demolition;

- Analysis of the geotechnical situation;

- Availability of residential complexes on the territories of integral development;

-The possibility of building of high-rise complex and unique buildings;

At stages 6-9 the analysis of the necessity of relocation and demolition, geotechnical situation was fulfilled.

To analyze of the availability of residential complexes it is required the usage of electronic cards of Rostov-on-Don, as well as assessing the real estate market.

Table 5. Analysis of the availability of residential complexes on the territories of the integrated development

\begin{tabular}{|l|l|l|l|l|}
\hline & \multicolumn{1}{|c|}{$\begin{array}{c}\text { Territory } \\
\text { №1 }\end{array}$} & \multicolumn{1}{c|}{ Territory №2 } & \multicolumn{1}{c|}{ Territory №3 } & \multicolumn{1}{c|}{ Territory №4 } \\
\hline $\begin{array}{l}\text { The number of } \\
\text { residential } \\
\text { complexes } \\
(2017)\end{array}$ & 0 & $\begin{array}{l}3 \\
\text { "Aquamarin", "On } \\
\text { the Sedov } \\
\text { street","Quiet } \\
\text { Don" }\end{array}$ & $\begin{array}{l}\text { "Izmail Park", } \\
\text { "Horizon " }\end{array}$ & $\begin{array}{l}\text { "Cascade, New } \\
\text { town " }\end{array}$ \\
\hline
\end{tabular}

Thus, the greatest number of residential complexes identified in No. 2.

To assess the possibility of building in the territories of integrated development of complex high-rise buildings is necessary from the point of view of the feasibility of placing the building of high-rise buildings in the area. When selecting property one must take into account the architectural appearance of buildings and structures. The construction of a detached high-rise unique building could disrupt the architectural integrity of the urban composition, in this connection, it is expedient to build a complex of high-rise residential buildings. During the construction of the unique complex of high-rise buildings should 
consider the idea of creating a demonstration zone high-tech, zone of superior comfort or a whole district of high-rise and unique buildings.

For the final updated assessment with additional factors applied to the same sequence of actions as in the comprehensive assessment areas, using the main factors. As the evaluation factors are 4 additional indicator, and then calculates successively the formulas (1), (2), (3) and (4).

The results of the calculation are summarized in table 6 .

Table 6. Rating of functional priority territories for integrated development high-rise and unique construction

\begin{tabular}{|l|c|c|}
\hline \multirow{2}{*}{ №n/ח } & \multicolumn{2}{|c|}{ The rating of high-rise and unique buildings depending on the } \\
& Runction \\
\cline { 2 - 3 } & Residential area & Public-business zone \\
\hline Territory No 1 & 10.82 & 10.90 \\
\hline Territory No 2 & 11.10 & 11.69 \\
\hline Territory No 3 & 13.12 & 12.27 \\
\hline Territory No 4 & 12.00 & 11.31 \\
\hline
\end{tabular}

\section{Results}

Stage 11: Selection of areas of integrated development with the highest rating According to the functional priority for building unique buildings, calculated in stage 10, the highest priority was the area No. 3 .

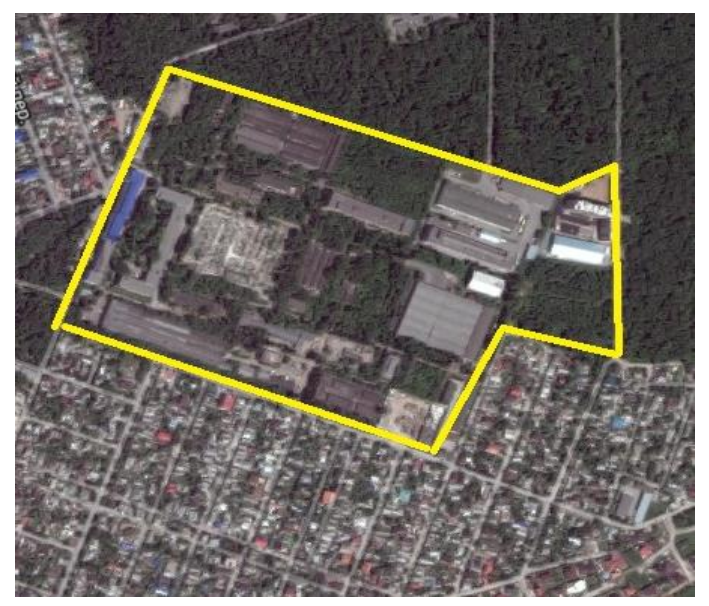

Fig. 6. The selected area of comprehensive development

Territory No. 3 is located in the Voroshilov district, the area of 608 thousand $\mathrm{m} 2$. This area is located in the area of less dangerous geological and environmental risk, low noise, no landslides and flooding.

\section{Conclusions}

The developed method has allowed to solve the problem of choosing the most suitable for the construction of high-rise and unique buildings of the territory integrated development. Deciding on the best location for the building has always been an acute problem, both investors and customers in connection with a large number of factors that must be considered 
when choosing a site for the future construction project. On the other hand, the development of the construction industry and the emergence of new types of buildings require review of standard procedures for the selection of site for facility construction in connection with the introduction of new building technologies, new materials, new requirements of modern facilities. Unique high-rise building, like any new branch of the construction industry, has its own characteristics, norms and requirements. The right choice of site for the construction of tall unique buildings should be based on consideration of factors that are of importance for this type of buildings.

Discussed in the article additional factors were presented on the base of the unique characteristics of high-rise construction in general. The final rating score assigned to the territories of complex development, can be used as justification for selecting this site, and may change depending on user settings. Methodology choice of site complex development, designed for high-rise and unique construction will allow investors and customers to assess not only environmental, geological and other standard risk factors, but also take into account the investment attractiveness of the future of the unique object to the proposed site.

\section{References}

1. The town-planning code of the Russian Federation of 29.12.2004 N 190-FL (ed. from 29.07.2017). Article 46.10. Integrated development on the initiative of local authorities. -FL of 03.07.2016 N 373-FL.

2. The city-planning code of the Russian Federation of 29.12.2004 N 190-FL (ed. from 29.07.2017). Article 46.9. Integrated development on the initiative of the authorities land owners and (or) located on them of objects of real estate. -FL of 03.07.2016 N 373-FL.

3. S. G. Sheina, L. L. Babenko, R. B. Matveyko, A. A. Kamalova. Complex assessment of the territory in urban construction (Rostov State University of Civil Engineering, 2015)

4. S. G. Sheina, L. V. Gyria. Organizational and technological support of the reconstruction of urban development with consideration of ecological monitoring of the territory (Rostov State University of Civil Engineering, Rostov n/D, 2012)

5. S. S. Bachurina. Metropolis: methods and models for process control of complex reconstruction of existing buildings (SINTEG, Moscow, 2004)

6. L. B. Zelentsov, S. G. Sheina. The control system of quality of reconstruction of urban development (Rostov State University of Civil Engineering, Rostov n/D, 2005)

7. V. F. Kasyanov. Reconstruction of the residential development of cities. Textbook. (Association of building Universities, Moscow, 2005)

8. Russian Standard SNiP 2.07.01-89* Urban development planning and construction of urban and rural settlements.

9. N. P. Shepelev, M. S. Shumilov. The reconstruction of urban development. Textbook. (Highest school, Moscow, 2003)

10. M. A. Gyria. Organizational and technological support of the reconstruction of urban development on the basis of state monitoring of the geological environment. $\mathrm{PhD}$ Thesis, Rostov n/D, (2007)

11. A. V. Gridnevsky. Methods of collecting and processing information for monitoring of geodynamic hazards of urban areas. (Rostov State University of Civil Engineering, 2016)

12. A. V. Grinevskii, S. G. Sheina. Monitoring and assessment of geological hazards of the territories of the Rostov region (Rostov State University of Civil Engineering (2015) 
13. A. V. Gridnevsky. Materials of year session of scientific Council of RAS on problems of geoecology, engineering geology and hydrogeology, 14 (2012)

14. A. V. Gridnevsky. Sergeev readings: materials of annual session of RAS Scientific Council on problems of Geoecology, engineering Geology and hydrogeology (2014)

15. A. V. Gridnevsky, S. G. Sheina. Possibilities of radar imagery of the earth's surface for monitoring of geodynamic hazards of urban areas (Rostov n/D, Rostov State University of Civil Engineering, 2015) 